\title{
Judicial Review of the Facts in Informal Rulemaking: A Proposed Standard
}

Administrative action based on predictions in areas of complex technology ${ }^{1}$ is commonly undertaken through informal rulemaking. Recently courts have been uncertain about the proper degree of scrutiny in reviewing the factual basis of such actions.

In an effort to derive a workable standard of judicial review for informal rulemaking, this Note examines the functional roles of the traditional standards of review, "arbitrary and capricious" and "substantial evidence." The Note argues first that the substantial evidence test should be adopted as the standard of factual review for informal rulemaking. Second, the Note proposes that the reviewing stance for factual determinations should be explicitly recognized as a flexible one, varying with the determinability of the facts and with the statutory mandate of the agency. When the factual basis for action is necessarily uncertain, or when Congress has identified dangers to the public health and welfare to be avoided regardless of cost to competing economic or social goals, the courts should hold agencies to a lower standard of factual proof.

\section{The Traditional Standards of Review}

As a basis for judicial review of agency determinations of fact, ${ }^{2}$ the Administrative Procedure $\mathrm{Act}^{3}$ establishes two alternative standards of scrutiny, "arbitrary and capricious" and "unsupported by substantial evidence." 4 Which standard will be applied in review of agency deter-

1. For discussion of the special problems posed by technical regulatory decisions, see Boyer, Alternatives to Administrative Trial-Type Hearings for Resolving Complex Srit'lltific, Economic, and Social Issues, 71 MICH. L. REv. 111 (1972); Gelpe \& Tarlock, The Uses of Scientific Information in Environmental Decisionmaking, 48 S. C.1L. L. REv. 371 (1974); Reich, The Law of the Planned Society, 75 YALE L.J. 1227 (1966); Tribe, Technology Assessment and the Fourth Discontinuily: The Limits of Instrumental Rationality, 46 S. CaL. L. REv. 617 (1973).

2. In any scrutiny of administrative action, the reviewing court must ascertain first whether the agency has acted within its statutory mandate; second, whether the agency has adequately demonstrated the facts it relies on: and third, whether the agency's policy choice can rationally follow from the facts adduced. The second and third reviewing tasks in effect draw the familiar distinction between judicial scrutiny of ques: tions of fact and judicial scrutiny of questions of law. See L. JAFFE, JUdiciaL Control of ADMInistrative Action 546-65 (1965). In Judge Friendly's terminology, the distinction is between "insufficient or erroneous findings" and "unstustainable reasons." Friendly, Chenery Revisiled: Reflections on Reversal and Remand of Administrative Orders, 1969 DUkE L.J. 199, 209-22.

3. 5 U.S.C. $\$ \$ 501-706(1970)$ [hereinafter cited as APA].

4. 5 U.S.C. $\$ 706(2)(A)$, (E) (1970). The former standard is worded in the statute "arbitrary, capricious, an abuse of discretion, or otherwise not in accordance with law," but is usually denominated merely "arbitrary and capricious." 
minations of fact depends on the type of agency proceeding ${ }^{5}$ and the attendant standard provided in the Administrative Procedure Act, and on any special standard of review imposed by the particular regulatory act.

The potential difference between the standards of "arbitrary and capricious" and "substantial evidence" is limited to the review of factual determinations. However formal the type of agency proceeding, an agency's policy choices are reviewed under the arbitrary and capricious standard, which asks merely whether the policy choice is rationally connected to its factual basis. ${ }^{6}$ The substantial evidence standard applied in adjudication and formal rulemaking has been confined to evaluating the factual basis for decisions. ${ }^{\top}$

The interpretation given to the two standards with respect to factual determinations has changed considerably over time. At first, under either test, administrative agency action received extreme deference. Reviewing courts applying the substantial evidence standard often felt obliged to sustain agency findings if supported by some evidence anywhere in the record, "without reference to how heavily the countervailing evidence may preponderate."s In 1951, Universal Camera Corp. v. $N L R B^{9}$ reinterpreted the standard of substantial evidence as imposing a heavier burden of justification on the agency. The reviewing court was to evaluate the record as a whole to determine whether it reasonably supported an agency conclusion. ${ }^{10}$ The arbitrary and capricious standard of review still required only that the agency

5. The Administrative Procedure Act recognizes four formats for administrative decisionmaking. In descending order of procedural formality, they are adjudication (5 U.S.C. \$551 (1970)); formal rulemaking (5 U.S.C. \$ 553(c) (1970), invoking the formal procedures of $\$ \$ 556$ and 557 "when rules are required by statite to be made on the record after opportunity for an agency hearing"); informal rulemaking (5 U.S.C. $\$ 553(c)$ $(1970)$ ); and nonformalized decisionmaking (5 U.S.C. $\$ 553(\mathrm{a}),(\mathrm{b})(\mathrm{A})$, , (B) $(1970)$, and any agency action not included in the definitions of "rate," "order," "adjudication," "li-
cense," or "sanction," 5 U.S.C. $\$ 551(4),(6),(7),(8),(10)(1970)$ ). These four modes of decisionmaking are generally invoked explicitly or implicitly in the enabling acts establishing and giving powers to administrative agencics.

6. SEC v. Chenery Corp., 318 U.S. 80 (1943). See also Friendly, supra note 2, at 209-17.

7. This differing scrutiny of facts and of policy was most recently approved in Bowman Transp., Inc. v. Arkansas-Best Freight Sys., 419 U.S. 281, 284-85 (1974). Unfortunately, regulatory statutes providing specifically for substantial evidence review often fail to state that the standard applies only to facts and not to policy.

8. Universal Camera Corp. v. NLRB, 340 U.S. 474, 481 (1951).

9. Id.

10. Id. at 490 . The evidentiary burden of the agency under the substantial evidence standard has been variously stated. One frequently invoked formulation, retaining vitality even after Universal Camera, is that of Consolidated Edison v. NLRB, 305 U.S. 197, 229 (1938): "Substantial evidence is more than a mere scintilla. It means such relevant evidence as a reasonable mind might accept as adequate to support a conclusion." See also Consolo v. Federal Maritime Comm'n, 383 U.S. 607, 620 (1966):

'The possibility of drawing two inconsistent conclusions from the evidence does not prevent an administrative agency's finding from being supported by substantial evidence. 
act with rationality and consistency. ${ }^{11}$ "Arbitrary and capricious" review thus came to be considered "soft" or cursory, while substantial evidence implied more searching review of agency action.

\section{Substantial Evidence Review of Informal Rulemaking}

The notice and comment procedures of informal rulemaking ${ }^{12}$ have the advantage of allowing effective public participation in agency decisionmaking without requiring the time-consuming formalities of adjudication and formal rulemaking. ${ }^{13}$ This ease of procedure has led Congress to frequently specify informal rulemaking for agency decisions under new regulatory statutes. ${ }^{14}$

The Administrative Procedure Act is susceptible to a reading requiring substantial evidence review of factual determinations in informal rulemaking. The substantial evidence standard, according to the APA, applies to formal rulemaking, adjudication, and cases "otherwise reviewed on the record of an agency hearing provided by statute." 15 If this last category is to have any referent, it must be to informal rulemaking notice and comment procedures, for they are the only procedural format other than formal rulemaking and adjudication that produces a "record." 16 The informal rulemaking pro-

11. See, e.g., Superior Oil Co. v. FPG, 322 F.2d 601 (9th Cir. 1963), cert. denied, 377 U.S. 922 (1964).

12. Notice and comment procedures are set out in the APA, 5 U.S.C. $\$ 553(\mathrm{~b})-(\mathrm{e})$ (1970). Typically an agency will formulate a proposed regulation, then publish it in a notice in the Federal Register inviting comments from interested parties. After the agency has considered the comments, it either reformulates the regulation in light of the comments or adopts the proposed regulation as its final decision. Finally, the adopted rules are published along with a statement of their basis and purpose.

13. Adjudicatory hearings and formal rulemaking proceedings, conducted under 5 U.S.C. $\$ \$ 556$ and 557 , approximate the procedure of a civil trial. However, the right of cross-examination is limited to that "required for a full and true disclosure of the facts." 5 U.S.C. $\$ 556(d)(1970)$. In formal rulemaking, all or part of the evidence can be submitted in written form if the parties will not be prejudiced.

I4. E.g., Consumer Product Safety Act, 15 U.S.C. \$2058(a)(2) (Supp. III 1973); Flammable Fabrics Act of 1967, 15 U.S.C. $\$ 1193$ (1970); Occupational Safety and Health Act of 1970, 29 U.S.C. $\S 655($ b) $(1970)$. See Clean Air Amendments of 1970, 42 U.S.C. $\$ 1857 a$ (1970).

15. 5 U.S.C. $\$ 706(2)(\mathrm{E})(1970)$.

16. The original House report on the APA makes clear that $\$ 553$ informal rulemaking was thought to produce a record:

The agency must keep a record and analyze and consider all relevant matter presented prior to the issuance of rules. The required statement of the basis and purpose of rules issued should not only relate to the data so presented but with reasonable fullness explain the actual basis and objectives of the rule.

House Comm. on the Judiciary, Administrative Procedure Act, H.R. Rer. No. 1980, 79 th Cong., 2d Sess. 25 (1946).

The record of informal rulemaking consists at a minimum of the Federal Register notice, all comments submitted to the agency and other information compiled by the agency. The record may be unfocused because the evidence is generally not shaped by cross-examination or oral argument. Such a record may be somewhat difficult to review. See Robinson, The Making of Administrative Policy: Another Look at Rulemaking and 
cedures have also been held to constitute a "hearing." 17

In practice, however, the applicable standard is disputed. The Supreme Court has stated in dicta ${ }^{18}$ that substantial evidence review governs informal rulemaking under the Administrative Procedure Act and has resolved a number of cases by that standard. The lower courts have nonetheless restricted use of the substantial evidence standard to adjudication and formal rulemaking while using the arbitrary and capricious standard to review informal rulemaking. ${ }^{19}$

\section{A. Arbitrary and Capricious": A Standard Made Rigorous}

The difference between the standards of review has narrowed in the face of the increased use of agency rulemaking powers. The substantial evidence standard has been applied as a rather flexible gauge of the quantum of facts necessary to establish a basis for agency action. ${ }^{20}$ At the same time the arbitrary and capricious standard for review of facts has been applied more rigorously.

Adjudication and Administrative Procedure Reform, 118 U. PA. L. REv. 485, 519, 525 (1970); Verkuil, Judicial Review of Informal Rulemaking, 60 VA. L. REv. 185, 222-26 (1974). But see p. 1760 infra. The focus of the record can be sharpened if the agency gives a full explanation of its evaluation of the record in its required statement of basis and purpose (5 U.S.C. $\$ 553(\mathrm{c})$ ) and if the parties cite to relevant parts of the record in their appellate briefs. For possible procedures to improve the informal rulemaking record, see Pedersen, 85 YaLE L.J. (forthcoming).

17. The notice and comment procedures of $\$ 553$ have been treated by the Supreme Court as equivalent to a "hearing" within the meaning of the Administrative Procedure Act. In United States v. Florida E. Coast Ry., 410 U.S. 224 (1972), the Court approved a broad definition of "hearing" as including both $\$ 553$ notice and comment procedures and $\$ \$ 556-57$ proceedings that use written rather than oral evidence.

The immediate issue before the Court in Florida East Coast Railway was whether the Interstate Commerce Commission's procedures for freight car ratemaking had complied with the requirements of a hearing under $\$ 1(14)$ of the Interstate Commerce Act. 49 U.S.C. $\$ I(14)(1970)$. In holding that the procedures were adequate, the majority relied on United States v. Allegheny-Ludlum Steel Corp., which established that the $\$ 1(14)$ hearing requirement is satisfied by $\$ 553$ notice and comment procedures. United States v. Allegheny-Ludlum Steel Corp., 406 U.S. 742, 756-57 (1972). The Court also relied on the language of $\$ 553(\mathrm{~b})$ of the Administrative Procedure Act, which makes $\$ 553$ procedures applicable to interpretative rules when a "hearing is required by statute." 5 U.S.C. $\$ 553(\mathrm{~b})$, cited in 410 U.S. at $240-41$. The Court thus defined the $\$ 1(14)$ hearing requirement by reference to the scope of an Administrative Procedure Act "hearing" under $\$ 553$.

Note that under the APA a "hearing" is distinct from a "hearing on the record." The latter invokes formal rulemaking procedures. United States v. Allegheny-Ludlum Steel Corp., supra at 757. See also Friendly, "Some Kind of Hearing," 123 U. PA. L. REV. 1267, 1313 (1975).

18. See pp. 1756-57 infra.

19. Amoco Oil Co. v. E.PA, 501 F.2d 722 (D.C. Cir. 1974) (applying arbitrary and capricious standard to informal rulemaking); City of Chicago v. FPC, 458 F.2d 731 (D.C. Cir. 1971), cert. denied, 405 U.S. 1074 (1972); Automotive Parts \& Accessories Ass'n, Inc. v. Boyd, 407 F.2d 330 (D.C. Cir. 1968). But see Chrysler Corp. v. Department of Transp., 472 F.2d 659 (6th Cir. 1972) (applying substantial evidence review to informal rulemaking); cf. Bunny Bear, Inc. v. Peterson, 473 F.2d 1002, 1006 (1st Cir. 1973) (applying arbitrary and capricious review but characterizing it as "differ[ing] little, if at all, from the standard normally used in substantial evidence review").

20. See note 48 and pp. 1761-62 infra; see also Society of Plastics Indus., Inc. v. OSHA, 509 F.2d 1301 (2d Gir. 1975); 4 K. DAvis, Administrative LAw Treatise $\$ 29.02$, at 126 (1958) (the substantial evidence rule "is made of rubber, not of wood"). 
The lower courts' more rigorous use of the arbitrary and capricious standard in review of informal rulemaking can be traced to two developments in the case law. First, the Supreme Court made clear in Citizens to Preserve Overton Park $v$. Volpe $e^{21}$ that a stronger interpretation of the arbitrary and capricious standard was warranted in application to nonformalized decisionmaking:22

[T] he generally applicable standards [of judicial review under the Administrative Procedure Act] require the reviewing court to engage in a substantial inquiry. Certainly, the Secretary's decision is entitled to a presumption of regularity. . . . But that presumption is not to shield his action from a thorough, probing, in-depth review. ${ }^{23}$

The reviewing court was to scrutinize the facts and consider whether the decision was "based on a consideration of the relevant factors and whether there has been a clear error of judgment."24 Such supervision

21. 401 U.S. 402 (1971).

22. The subsequent decision in Camp v. Pitts, 411 U.S. 138 (1973), does not diminish the rigor which the Supreme Court infused into the arbitrary and capricious standard in Overton. Camp established that the further submission of information to facilitate judicial review of nonformalized decisionmaking did not extend to having a de novo hearing in the reviewing court. Instead, the agency was to provide "either through affidavits or testimony, such additional explanation of the reasons for the agency decision as may prove necessary." Camp v. Pitts, 411 U.S, at 143. The Court then noted that the brief explanation by the Comptroller of the Currency of his decision to grant a bank charter might be adequate in light of the underlying record. Id.

Professor Verkuil has argued that this amounts to approval of a loosening of the stringency of review found necessary in Overton Park. Verkuil, supra note 16, at 213-14. Such an interpretation is unwarranted in light of the procedural and substantive posture of Camp. First, the Supreme Court did not undertake substantive revicw of the Comptroller's decision in Camp and thus had no occasion to examine the agency record for support of the agency's finding that a new bank was an "uneconomic venture." The Court's remark was thus merely a prediction as to what factual showing might prove sufficient upon remand to the district court. Second, the Comptroller's responsibility for granting bank charters in Camp was broadly discretionary, whereas the Department of Transportation's policy choice under Overton Park was highly structured and confined. Compare Federal-Aid Highway Act of 1968, 23 U.S.C. $\$ 138$ (1970) and Department of Transp. Act, 49 U.S.C. $\$ 1653(f)(1970)$ (the Secretary "shall not approve any program or project" that requires the use of any public parkland "unless (1) there is no feasible" and prudent alternative to the use of such land, and (2) such program includes all possible planning to minimize harm to such park") (emphasis added) with National Bank Act, 12 U.S.C. $\$ 27$ (1970) ("If, upon a careful examination of the facts so reported, and of any other facts which may come to the knowledge of the comptroller . . it appears that such association is lawfully entitled to commence the business of banking. the comptroller shall give to such association a certificate . . .") (emphasis added).

Given the broad discretion in awarding bank charters that is confided to the Comptroller under the statute, a simple explanation of his decision may have been all that was required to guard against arbitrary action. So long as the factual base rationally supported his findings and policy decision, the existence of 20 better dispositions would be irrelevant. The apparent brevity of analysis is linked to this breadth of policy discretion. For another example, see Di Vosta v. Lee, 488 F.2d 674 (5th Cir. 1973) (arbitrary and capricious review of agency decision based in part on environmental impact statements, where agency had a substantial degree of discretion). See also K. Divis, ADMINISTRATIVE LAw TEXT $\$ 30.06$, at 533 (1972).

23. 401 U.S. 402,415 (1970) (emphasis added).

24. Id. at 416 . However, "the court is not empowered to substitute its judgment for that of the agency." Id. 
of the factors considered by an agency and the rationality of its policy choice was a considerable departure from the traditional deference ${ }^{25}$ characterizing arbitrary and capricious review. Since nonformalized decisionmaking provides the baseline for judicial scrutiny of administrative action, Overton's rigor would have seemed appropriate for informal rulemaking.

Second, even before Overton was decided, the courts of appeals had begun stricter review of informal rulemaking under the rubric of "arbitrary and capricious." ${ }^{26}$ Although dictum in Overton seems to have stated that the substantial evidence standard should be used for informal rulemaking review, ${ }^{2 \tau}$ the appellate courts instead relied on Overton's "arbitrary and capricious" language, 28 and assumed that it supported their current reviewing stance. ${ }^{29}$

The new bite of arbitrary and capricious review by the courts of appeals is evidenced in the remanding of decisions to the rulemaking agency and in the courts' careful evaluation of complex and often probabilistic evidence. ${ }^{30}$ Despite this increased rigor, however, the

25. See, e.g., Judge Bazelon's discussion of the history of administrative review in Environmental Defense Fund v. Ruckelshaus, 439 F.2d 584, 597-98 (D.C. Cir. 1971). For a traditional interpretation of arbitrary and capricious as a lenient standard, see $4 \mathrm{~K}$. Davis, supra note $20, \$ 30.05$, at 213-14. See also note 11 supra.

26. E.g., Automotive Parts \& Accessories Ass'n, Inc. v. Boyd, 407 F.2d 330 (D.C. Cir. 1968).

27. See pp. $1756-57$ infra.

28. See language quoted at p. 1754 supra; Citizens to Preserve Overton Park v. Volpe, 401 U.S. 402, 416 (1971).

29. See South Terminal Corp. v. EPA, 504 F.2d 646, 655 (1st Cir. 1974); Portland Coment Ass'n v. Ruckelshaus, 486 F.2d 375, 402 (D.C. Cir. 1973), cert. denied, 416 U.S. 921 (1974); Essex Chem. Corp. v. Ruchelshaus, 486 F.2d 427, 434 (D.C. Cir. 1973); City of Chicago v. FPC, 458 F.2d 731 (D.C. Cir. 1971).

30. For example, in Essex Chem. Corp. v. Ruckelshaus, 486 F.2d 427 (D.C. Cir. 1973), the court reviewed the Environmental Protection Agency's stationary source regulations under the Clean Air Act. The court upheld the regulation limiting emissions from elemental sulfur feedstock plants primarily on the basis of company-supplied test data. It was unimpressed with the EPA's own test results because they were not carried out under conditions in accord with previously promulgated EPA regulations requiring plant operation at capacity. The court remanded the EPA's performance standards for generator plants because the scrubber systems chosen by the agency were not first analyzed for "counter-productive environmental effects" resulting from disposal of their liquid byproduct. The court in Essex thus carefully scrutinized the factual evidence supporting the final policy choice and the reasonableness of the inferences the agency had drawn from the evidence.

Similarly in Amoco Oil Co. v. EPA, 501 F.2d 722 (D.C. Cir. 1974), close factual review was undertaken by the court. Under the Clean Air Amendments of 1970, the EP.A administrator had issued interim standards requiring catalytic converters on a substantial number of automobiles by the 1975 model year. $A$ moco involved a challenge to regulations that established a ceiling of 0.05 grams per gallon for the lead content of gasoline. The court noted that uncontradicted evidence was introduced that catalytic converters were poisoned by gasoline averaging more lead than $0.05 \mathrm{gram} / \mathrm{gallon}$, that the $0.07 \mathrm{gram}$ gallon standard suggested by the refiners was based on refinery and distribution standards irrelevant under the statute, and that the practical experience of the Amoco Oil Company showed no scientific or technological obstacles to meeting the lower ceiling. On the basis of this close review of the evidence, the court concluded that the El'I could reasonably make the policy choice of a 0.05 gram/gallon ceiling.

See also CPC Int'l, Inc. v. Train, 43 U.S.L.T. $246 \overline{7}$ (8th Cir. May 5,1975 ) (new source 
courts of appeals still frequently characterize the arbitrary and capricious test as a lesser standard of review than the substantial evidence test. ${ }^{31}$ Courts of appeals also have differed on whether additional procedures are necessary to prepare an informal rulemaking record suitable for careful factual scrutiny. ${ }^{32}$

\section{B. "Substantial Evidence" and Overlooked Dicta}

The Supreme Court has made no indisputable ruling that substantial evidence review of the facts is required for informal rulemaking under the Administrative Procedure Act. However, the cases in which the Court has reviewed or discussed informal rulemaking-Citizens to Preserve Overton Park v. Volpe, United States v. Midwest Video Corp., ${ }^{33}$ and United States $v$. Allegheny-Ludlum Steel Corp. $.^{34}-$ seem to assume that "substantial evidence" is the applicable standard under the APA. ${ }^{35}$ In Overton Park, the Court suggested in dicta that substantial evidence review applies:

Review under the substantial-evidence test is authorized only when the agency action is taken pursuant to a rulemaking provi-

standards under the Federal Water Pollution Control Act for the corn wet milling industry held arbitrary and capricious because no evidentiary support to establish that available technology would be effective when applied within the industry).

31. In Consumers Union v. Consumer Prod. Safety Comm'n, 491 F.2d 810 (2d Cir. 1974), Judge Timbers hypothesized additional explanations for the agency's action, beyond those offered by the agency itself, in a manner reminiscent of the old "cursory" arbitrary and capricious review. See also Ethyl Corp. v. EPA, 7 ENviron. REP. CAS. 1382 (D.C. Cir. Jan. 28, 1974) (Wright, J., dissenting), vacated on order granting rehearing en banc, No. 73-2205 (D.C. Cir. Mar. 17, 1975), reheard en banc (D.C. Cir. May 30, 1975), quoted in note 46 infra; Wright, The Courts and the Rulemaking Process, 59 CoRNELI. L. REv. 375, 392-93 (1974).

32. Compare South Terminal Corp. v. EPA, 504 F.2d 646, 660-61 (Ist Cir. 1974) (rejecting extra procedures) with International Harvester v. Ruckelshaus, 478 F.2d 615, 629-31, 649 (D.C. Cir. 1973) (requiring extra procedures).

This continued concern with extra procedures needed to provide an illuminating record for the reviewing court suggests that many courts are taking seriously Overton Park's command of careful factual scrutiny. See, e.g., Portland Cement Ass'n v. Ruckelshaus, 486 F.2d 375 (D.C. Cir. 1973); Mobil Oil v. FPC, 483 F.2d 1238 (D.C. Cir. 1973); Walter Holm \& Co. v. Hardin, 449 F.2d 1009 (D.C. Cir. 1971).

The conclusion that procedures in addition to notice and comment are not required as a matter of due process or statutory construction of the APA is well-supported in the literature. See generally Wright, Court of Appeals Review of Federal Regulatory Agency Decisionmaking, 26 AD. L. REv. 199 (1974); Wright, supra note 31; Note, The Judicial Role in Defining Procedural Requirements for Rulemaking, 87 HARv. L. REV. 782 (1974). But see Friendly, supra note 17, at 1314-15, who suggests that the ad hoc use of additional procedures reaches largely the same result as the accepted practice of remanding because of inadequate evidence. Nonetheless, insistence on adequate notice and comment procedures at the agency level seems preferable as a matter of practice.

33. 406 U.S. 649 (1972).

34. 406 U.S. 742 (1972).

35. The only other Supreme Court case touching on the standard of review in informal rulemaking under the APA is American Trucking Ass'ns v. United States, 344 U.S. 298, 314, 304 (1953) ("evidence marshalled .. . plainly supports the conclusion that the continued effectiveness of [the ICC's] regulation requires the rules presented" and "evidence is overwhelming that ... practices directly affect ... the public interest in necessary service" (emphasis added)). 
sion of the Administrative Procedure Act itself, 5 U.S.C. $\$ 553$. . [informal and formal rulemaking], or when the agency action is based on a public adjudicatory hearing. See 5 U.S.C. $\$ \$ 556$, $557 \ldots$ [procedures for formal rulemaking and adjudicatory hearings $]^{36}$

Similarly, in United States $v$. Midwest Video Corp., the plurality opinion assumed that in Federal Communications Commission notice and comment procedures for formulating cable television regulations, the standard applicable to the record of written comments was whether the regulation was "supported by substantial evidence that it will promote the public interest." ${ }^{37}$ The Court concluded the standard was met only after reviewing the FCC's evidence on the cost of starting a cable television system and after examining the agency's consideration of the cost of originating programs. The Court again applied a substantial evidence standard to APA informal rulemaking in United States v. Allegheny-Ludlum Steel Corp., in review of Interstate Commerce Commission regulation of freight car shortages. ${ }^{38}$

36. 401 U.S. 402,414 (1971). The Court's reference to $\$ 553$ in the language quoted arguably might be intended to refer only to the formal rulemaking provision invoked by $\$ 553(\mathrm{c})$. Such an interpretation is unlikely, however, because $\$ 553$ is mainly devoted to setting out informal rulemaking procedures. Section 553 refers to formal rulemaking only in noting the instances when informal rulemaking procedures do not apply and resort must instead be made to the formal rulemaking procedures of $\$ \$ 556$ and 557 .

Sections 556 and 557 cover only formal rulemaking and adjudicatory procedures. If the Court had meant to confine the substantial evidence standard to formal rulemaking and adjudication, it might have cited more appropriately to $\$ \$ 556$ and 557 alone.

37. 406 U.S. $649,671,673$ (1972). Arguably, the substantial evidence standard might have been applied in Miduest Video only because of some special standard of review governing the FCC rather than the general review standards of the APA for informal rulemaking. According to National Broadcasting Co. v. United States, 319 U.S. 190, 224 (1943), decided before the passage of the APA, the governing standard of review of factual findings by the FCC was "supported by evidence." At the time, the following odd standard was mandated by the Communications Act of 1934:

[F]indings of fact by the Commission, if supported by substantial evidence, shall be conclusive unless it shall clearly appear that the findings of the Commission are arbitrary or capricious.

Act of June 19, 1934, ch. 652, $\$ 402(e), 48$ Stat. 1094.

However, this section was amended in 1952 to make FCG actions reviewable under the general review standards of the APA. See 47 U.S.C. $\$ 402(\mathrm{~g})(1970)$, invoking 5 U.S.C. $\$ 706(1970)$ (formerly codified as 5 U.S.C. $\$ 1009$ (e) (1952)). The Midwest Video Court's inse of the substantial evidence standard in 1972 was therefore governed by the APA standards generally applicable to informal rulemaking. Midwest Video's substantial evidence review could not properly have depended on National Broadcasting.

38. The Court held that

[t]he Commission's finding that there are recurring periods of significant length when there is not an adequate freight car supply to service shippers is supported by substantial evidence.

406 U.S. at 753. See also id. at 746:

Central to the justification for the [ICC's] promulgation of these rules is its finding

that there was a nationwide shortage of freight car ownership. The court below assumed the correctness of that finding, and we conclude that it was supported by substantial evidence.

The Court reviewed in detail evidence on the number of cars and practices of the railroads before concluding that there was sufficient support for the factual determinations underlying the ICC regulations. Id. at 749-53. 
In the courts of appeals, ${ }^{39}$ application of the substantial evidence standard to informal rulemaking has been rare ${ }^{ \pm 0}-\mathrm{a}$ result of the circuit court's assumption that the substantial evidence standard applies only when there is an adjudicatory record. ${ }^{41}$ In at least one instance, however, a court of appeals has recognized that the two standards of review are often functionally equivalent. ${ }^{42}$

\section{Explaining the Discrepancy}

In a sense it is peculiar that the Supreme Court has not granted certiorari in an informal rulemaking case to settle the conflict between its apparent assumption that the substantial evidence standard applies and the lower courts' continued adherence to the arbitrary and capricious standard. Of course the Supreme Court does not frequently re-

It might be argued that the substantial evidence standard used in Allegheny-Ludlum was mandated by special review standards applicable to the ICC before the APA was passed. See Assigned Car Cases, 274 U.S. 564, 580, 584 (1927) (findings of fact in rulemaking under the Esch Car Service Act are valid if there is "evidence to support the finding"); Western Paper Makers' Chem. Co. v. United States, 271 U.S. 268, 271 (1926) ("finding of the [ICC] is conclusive if supported by substantial evidence").

However, the review standards applied to the ICC before passage of the APA appear to have been imposed as a matter of ad hoc judicial practice rather than mandated by particular regulatory statutes. See ATT'y GeN. Comm. ON AdMINistrative Procedure, Report on Administrative Procedure in Governatent Agencies, S. Doc. No. 8, 77th Cong., Ist Sess. 89 (1941); see also New Eng. Div. Case, 261 U.S. 184, 203 (1923); Skinner \& Eddy Corp. v. United States, 249 U.S. 557, 562 (1919); ICC v. Union Pac. R.R., 222 U.S. 541, 547-48 (1912). Such nonstatutory review standards would be superseded by the statutory review standards of the APA.

39. Regulatory statutes often specify that the courts of appeals can review administrative action directly. See, e.g., Natural Gas Act, 15 U.S.C. $\$ 717 \mathrm{r}$ (b) (1970).

40. See note 19 supra.

41. E.g., City of Chicago v. FPC, 458 F.2d 731, 744 (D.C. Cir. 1971) (footnote omitted): The record in a[n informal rulemaking] proceeding ordinarily will contain more generalized than specific information, may not contain information tested by crossexamination and will frequently contain much conclusory information based on data gathered by the interested parties. For this reason, application of the substantial evidence test, defined and conceptualized as it frequently is in terms of whether or not a directed verdict should be granted in a jury trial, to findings resulting from a[n informal rulemaking] proceeding would be of scant utility.

42. Associated Indus. v. United States Dep't of Labor, 487 F.2d 342, 349.50 (2d Cir. 1973) (Friendly, J.): "[I]n the review of rules of general applicability made after notice and comment rulemaking, the two criteria do tend to converge." See also National Nutritional Foods Ass'n v. Weinberger, 512 F.2d 688, 705 (2d Cir. 1975) (Lumbard, J., concurring).

One example of such "convergence" is two cases arising under the National Highway Traffic and Motor Vehicle Safety Act of 1966, 15 U.S.C. $\$ \$ 1381-1431$ (1970). Each involved review by a court of appeals of informal rulemaking under the act. In Automotive Parts \& Accessories Ass'n, Inc. v. Boyd, 407 F.2d 330, 336-37 (D.C. Cir. 1968), the court applied the arbitrary and capricious standard in reviewing a regulation requiring mandatory head restraints in new automobiles. In upholding the regulation, Judge McGowan considered research and statistical evidence supporting the agency's conclusions about the safety value of head restraints and the appropriateness of installing them in the factory. In Chrysler Corp. v. Department of Transp., 472 F.2d 659, 668-70 (6th Cir. 1972), the court used a substantial evidence standard to examine the assumptions of the methodology used by the agency to justify air bag safety standards for cars. Here too the court examined technical and statistical evidence. The Automotive Parts court's analysis strikingly resembles the analysis undertaken in Chrysler in detail, scope, and methodology. 
view the scrutiny of administrative action by the courts of appeals. ${ }^{43}$ Nor is it clear that petitioners have recognized and argued the discrepancy in reviewing standards. The idiosyncratic facts of each case often conceal the development of generalized legal standards; the rulings the Court does make can be "distinguished" as limited to their special statutory and factual context. ${ }^{44}$ Perhaps most important, the arbitrary and capricious standard when rigorously applied in the lower courts can closely approximate the Supreme Court's use of the substantial evidence standard. The discrepancy may thus appear to petitioners and the Court to be more of form than of substance, not affecting the final outcome of the particular case.

\section{Substantial Evidence as a Proposed Standard of Review}

The new rigor of the arbitrary and capricious standard and the Supreme Court's recent use of substantial evidence in APA informal rulemaking evinces an emerging consensus on the desirable scope of review in rulemaking. The standard of review now employed, whatever the rubric, is "stricter" than the traditional cursory review. This rigor is desirable as a matter of consistency, because it resolves the possible anomaly posed by Overton of a less intrusive role for the reviewing court in informal rulemaking than in nonformalized decisionmaking. Practically, it provides a method of review that allows the court to curb and correct agency action contrary to law. The court is not empowered to substitute its judgment for that of the agency, but the legitimating effect ${ }^{45}$ of judicial review of administrative action is gained only after meaningful scrutiny of the adequacy of the agency's factual and policy grounds for action.

The explicit adoption of "substantial evidence" as the standard applicable to informal rulemaking under the APA would have the advantage of avoiding lapses from this relatively strict reviewing posture.

43. Most often certiorari is not granted unless some major statutory or procedural policy is at stake. See, e.g., Mobil Oil v. FPC, 417 U.S. 283, 310 (1974), quoting Universal Camera Corp. v. NLRB, 340 U.S. 474,491 (1951):

Whether on the record as a whole there is substantial evidence to support agency findings is a question which Congress has placed in the keeping of the Courts of Appeals. This Court will intervene only in what ought to be the rare instance when the standard appears to have been misapprehended or grossly misapplied. 44. The development of case law under each regulatory statute is surprisingly insular. This insularity stems from the delegation to the agencies of highly specialized powers in individual fields of competence. The viewpoint of Mr. Justice Harlan in the Permian Basin Area Rate Cases, 390 U.S. 747, 790 (1968), emphasizing the distinctiveness of agency action, is typical:

[T] he breadth and complexity of the [FPC's] responsibilities demand that it be given every reasonable opportunity to formulate methods of regulation appropriate for the solution of its intensely practical difficulties.

45. Cf. C. BLACK, JR., The PEOPLE AND the Court $47-51$ (1960). 
To the extent that arbitrary and capricious review is applied rigorously, using the substantial evidence label may seem merely a nominal change to conform the actual rigor to the statutory language of the APA. But an unequivocal holding by the Supreme Court announcing. the standard would insulate informal rulemaking from the lingering influence of the view that arbitrary and capricious review is properly deferential. ${ }^{46}$ Despite Overton Park, the notion of arbitrary and capricious review as deferring to agency assertions of fact, as demandingminimal rationality and consistency in reasoning, and as allowing judicial construction of a rationale for action when the agency fails to offer one, still overhangs the application of the arbitrary and capricious standard.

The Supreme Court's tacit use of the substantial evidence standard in such cases as Midwest Video and Allegheny-Ludlum suggests that there are no insuperable difficulties in applying the substantial evidence test to a record not shaped through adjudicatory procedures. ${ }^{47}$ The cases also suggest that "substantial evidence" can in practice be a flexible test accommodating the rigor of appellate scrutiny of the facts to the certainty with which the facts can be established. ${ }^{48}$

\section{Flexibility in Factual Review}

A clear holding by the Supreme Court that substantial evidence is the applicable standard of review would not fully clarify the reviewing

46. See, e.g., Judge Wright's dissent in Ethyl Corp. v. EPA, 7 Environ. Rep. Cas. 1382, 1400 (D.C. Cir. Jan. 28, 1975):

It may be that the courts are so willing to abandon the statutorily mandated "ar-

bitrary and capricious" standard because the standard is so singularly undemanding.

The extreme deference the statute demands of the reviewing court cuts against the

grain of judges who have been taught that their generalist backgrounds equip them

to provide dispassionate and comprehensive answers to any sort of problem. ...

Congress recognized that review of agency informal rulemaking was not a proper occasion for such activism.

47. Industrial Union Dep't v. Hodgson, 499 F.2d 467 (D.C. Cir. 1974); Mobil Oil v. FPC, 483 F.2d 1238 (D.C. Cir. 1973). But see Verkuil, supra note 16, at 222-26.

The concern that a record not shaped by adjudicatory cross-examination might be improperly weighted by the agency in favor of its own determination is not well-founded. The informal rulemaking notice and comment record has to include all negative com. ments received. The agency will also usually include all information supporting its posi. tion. The resulting record may be unfocused, but it is not incomplete. See Phillips Petroleum Co. v. FPC, 475 F.2d 842 (10th Cir. 1973) (adopting informal rulemaking procedures for the factually complex task of area ratemaking, where substantial evidence review was required under the Natural Gas Act, 15 U.S.C. $\$ 717 \mathrm{r}(\mathrm{b})(1970))$.

Gauging the adequacy of an administrative record by comparison to judicial adjudicatory records would be misleading, as an agency has the right to rely on its expertise in evaluating evidence. See, e.g., Market St. Ry. v. Railroad Comm'n, 324 U.S. 548 (1945).

48. The Supreme Court in Allegheny-Ludlum closely reviewed the inferences drawn from detailed factual findings about the availability of freight cars on the nation's railroads. 406 U.S. 742, 746-48, 749-53 (1972). By contrast, in Midwest Video, the Court found the substantial evidence standard to be satisfied by the agency's predictions about the financial ability of cable telecasters to cope with their new program responsibilities. 406 U.S. 649 (1972). 
court's responsibilities. For the mechanical labeling of review procedures has obscured the existing and necessary flexibility in the scope of judicial review. Complex, technical decisionmaking ${ }^{49}$ requires an adaptable approach.

\section{A. Case Studies}

Two recent cases applying to informal rulemaking a substantial evidence standard required by particular regulatory statutes have dealt explicitly with the problem of factual uncertainty.

Industrial Union v. Hodgson ${ }^{50}$ evaluated asbestos exposure regulations promulgated by the Department of Labor under the Occupational Safety and Health Act. ${ }^{51}$ The D.C. Circuit, in an opinion by Judge McGowan, recognized two classes of factual determinations: the class of "determinable facts" to be found from evidence in the record, and the class where factual certainties do not exist or "where facts alone do not provide the answer." 52 In the second "nondeterminable" class, the agency was required to state the uncertainties and then "go on to identify the considerations found persuasive." 33

Establishing an asbestos exposure limit to protect worker health involved the resolution of factual questions of this second type; "insufficient data [was] presently available to make a fully informed factual determination." 54 The final exposure standard had to be based on difficult predictions, such as the estimate that a certain percentage of asbestos workers would develop fatal cancers in two to three decades if subjected to some unknown level of exposure through a biological mechanism as yet unidentified. Confronted with such problematic questions on review, the court approved a strict exposure limit that resolved doubts in favor of the health of employees, even though "the evidence did not establish any one position as clearly correct." 55

49. Informal rulemaking powers have been granted and exercised most frequently under statutes designed to protect the environment, consumer safety, and occupational health. See note 14 supra. Regulation in these areas requires the ability to predict the effect on public health and welfare of changes in sophisticated technology and production methods.

50. 499 F.2d 467 (D.C. Cir. 1974).

51. 29 U.S.C. $\$ \$ 651-78$ (1970). OSHA provides for review of rulemaking under the substantial evidence standard. 29 U.S.C. $\$ 655(\mathrm{f})$. The court properly applied the substantial evidence test only to the facts. $499 \mathrm{~F} .2 \mathrm{~d}$ at 473 .

52. $499 \mathrm{~F} .2 \mathrm{~d}$ at 476 .

53. Id.

54. Id. at 474. The court described the facts as "on the frontiers of scientific knowledge." Id.

55. Id. at 478-79. The court noted that

reliable data is not currently available with respect to the precisely predictable

health effects of various levels of exposure to asbestos dust; nevertheless, the Sec-

retary [of Labor] was obligated to establish some specific level as the maximum permissible exposure. Id. at 475 . 
The Industrial Union court thus followed two important though implicit steps in dealing with factual uncertainty. First, it recognized that the required factual proof should vary directly with the potential for factual certainty. Second, the court recognized that the statutory policy preference for protection of employee health should also reduce the level of factual certainty required.

The Supreme Court similarly approved a lower level of factual proof for policy reasons in Mobil Oil v. FPC.56 The Court held that the substantial evidence standard, applied in the relatively certain factual context of Federal Power Commission rate setting, could properly be adjusted "in this time of acute energy shortage" degree of proof for novel FPC rate proposals. The FPC was thus held to be implicitly authorized, in carrying out its policy obligation of assuring the supply of gas, to consider the energy crisis as a justification for reducing its normal burden of factual proof. ${ }^{\text {ss }}$

\section{B. The Sliding Scale Standard}

Two variables thus shape the need for flexibility in factual review: the relative certainty of the factual data available, and the importance

56. 417 U.S. 283 (1974).

57. Id. at 331 .

58. The statute provided that supply was to be maintained by setting "just and reasonable rates." 15 U.S.C. $\$ 717(c)(a)(1970)$. The Court found that an inability to determine the amount of gas that would be found and sold under a proposed rate structure was allowable where the Commission's difficulties "did not stem from any failure to seek answers." 41 ' U.S. at 318 .

In the Permian Basin Area Rate Cases, 390 U.S. 747, 767,811 (1968), cited in Industrial Union v. Hodgson, 499 F.2d 467, 474-75 n.18 (D.C. Cir. 1974), the Supreme Court similarly recognized agency flexibility to act in the face of factual uncertainty in a new field of regulation, where existing methodology or research is deficient.

Several cases applying the "arbitrary and capricious" standard have also explicitly recognized that the standard for factual review is flexible. In Amoco Oil Co. v. EPA, 501 F.2d 722 (D.C. Cir. 1974), discussed supra note 30, the court deferred to EP.A's 0.05 gram/gallon ceiling for gasoline lead content for two stated reasons: first, the factual basis was "in the nature of a prediction for which supporting data is necessarily sparse or absent" (501 F.2d at 742); second, the agency was entitled to weigh as a matter of policy the competing risks involved in "underprotection as compared to overprotection." Id., citing Industrial Union v. Hodgson, supra at 475.

Texas v. EPA, 499 F.2d 289 (5th Cir. 1974), reached a similar result in regard to EPA rulemaking under the procedures of the Clean Air Act, where the agency rejected state implementation plans and substituted its own regulations. The statute required action, the Fifth Circuit concluded, and expressed a congressional policy choice to clean the environment and protect health even on the basis of "projections, assumptions and flimsy data." Id. at 319. The agency could properly allow for a "margin of crror" in setting standards to assure that congressional goals of air quality were achieved. Id. As the court applied it, this "margin of error" allowed a lower level of factual certainty.

[T] he agency's use of uncertain data is necessary if it is to perform its statutory

duty. In these circumstances we can only require that its data be the best that is feasibly available.

Id. The court did, however, impose a correlative duty on the agency to reconsider and revise its requirements as better data became available. Id. at $301 \mathrm{n} .16,919 \mathrm{n.49}$. Cf. Public Serv. Comm'n v. FPC, 511 F.2d 338 (D.C. Cir. 1975) (flexibility in factual review appropriate for an experimental program disallowed once the program could no longer be appropriately characterized as experimental). 
of the social risks at stake as weighed either by Congress or by the regulating agency. ${ }^{59}$ These variables, however, have not been synthesized into a reviewing stance generally applicable to informal rulemaking. Instead, they have been recognized hesitantly, on an ad hoc basis, as appropriate only to factually distinctive regulatory contexts. Arguably, cases shifting the burden of proof from the agency to parties challenging a regulation provide another legal mechanism for allowing flexibility in factual review; ${ }^{\circ 0}$ if neither side can "demonstrate" its factual assertions, assignment of the burden of proof effectively decides the case. ${ }^{01}$ But a standard that explicitly evaluates the appropriateness of flexibility in review of facts seems preferable to the unsystematic use of the burden of proof approach.

\section{Factual Determinability}

To make factual determinability a part of the sliding scale standard rests on a distinction between factual findings that courts are accustomed to making and facts that are not provable in the accepted juridical sense of proof. Short of an explicit statutory directive, ${ }^{62}$ the courts have resisted taking action on factual information that does not reach the level of certainty on which they are accustomed to rest decisions. ${ }^{63}$ Typical of apparently certain factual information is evidence

59. The statutory risk assessment may have to be implemented by a specific assessment of risk at the agency level. This agency judgment is of course a mixed question of fact and policy. See Ethyl Corp. v. EPA, 7 ENviron. Rer. Cas. 1382, 1393-94 (D.C. Cir. Jan. 28, 1975) (Wright, J., dissenting). For example, to carry out a congressional directive to ban all substances that pose a "grave danger" to workers' health at whatever economic cost, the agency must assess whether a particular substance is likely to pose such a danger.

60. See Environmental Defense Fund, Inc. v. EPA, 510 F.2d 1292, 1302 (D.C. Cir. 1975); Environmental Defense Fund, Inc. v. Ruckelshaus, 439 F.2d 584, 592 n.22, 594 n.37 (D.C. Cir. 1971). See also Leventhal, Environmental Decisionmaking and the Role of the Courts, 122 U. PA. L. REV. 509, 535-36 (1974) (useful elaboration of the burden of proof approach).

61. In practice, of course, the court may go on to analyze the cvidence despite the formal shift in burden. In Environmental Defense Fund, Inc. v. EPA, 510 F.2d 1292 (D.C. Cir. 1975), the court assigned the burden of proof to the opponents of the agency's suspension of the registration of two pesticides, but also analyzed the evidence throughout in terms of the stacutorily specified substantial evidence standard. The interrelationship of the two approaches was not made clear. Sce also International Harvester Co. 1 . Ruckelshaus, 478 F.2d 615, 643, 650-51 (D.C. Cir. 1973), and Judge Leventhal's subsequent commentary, supra note 60 , at 535-36.

62. E.g.; the Food, Drug and Cosmetic Act defines "substantial evidence" for new drug applications as including experimental results which otherwise might be considered of insufficient reliability.

[Substantial evidence includes] adequate and well-controlled investigations . . . on the basis of which it could fairly and responsibly be concluded by [trained and experienced] experts that the drug will have the effect it purports . ... 21 U.S.C. \$ 355 (d) $(1970)$.

63. See, e.g., Reserve Mining Co. v. EPA, 498 F.2d 1073 (8th Cir.), application to vacate stay of injunction denied, 418 U.S. 911 (1974), injunction modified after rehearing en banc, 514 F.2d 492 (8th Cir. 1975). The Eighth Circuit originally stayed injunctive relief 
about past events, such as ratemaking evidence. ${ }^{64}$ Typical of uncertain information would be predictions of future events where there is no past experience on which to rely-e.g., the performance capacities of technology yet to be developed or the percentage of the population likely to develop cancer after exposure to a newly suspected carcinogen. ${ }^{65}$

Regulatory statutes requiring preventative or curative action to be undertaken on the basis of predictions of future harm necessarily conflict with the court's predisposition to require evidence of past events as a basis for intervention in the private sector. The factual determinability component of the sliding scale standard would make it the reviewing court's responsibility to assure that the available evidence used in making predictions is adequately adduced and rationally applied. But factual certainty in the sense of presently complete information on the likely impact of future events could not be required.

\section{Competing Risks}

The policy component of the sliding scale test reflects whether there has been a congressional reconciliation of competing societal risks, subordinating normally protected goals to another more highly valued goal. The policy values underlying analysis of risk can be found in the enabling legislation or in the agency's implementation of the congressional value choice. For example, Congress may decide to protect workers' health on the job even at the price of closing down a business or radically altering business production methods. If a risk is iden-

against the discharge of asbestos into Lake Superior because it deemed the evidence of a threat to public health to be uncertain.

Plaintiffs have failed to prove that a demonstrable health hazard exists. This failure, we hasten to add, is not reflective of any weakness which it is within their power to cure, but rather, given the current state of medical and scientific knowledge, plaintiffs' case is based only on medical hypothesis and is simply beyond proof. . . . [T]he district court's determination to resolve all doubts in favor of health safety represents a legislative policy judgment, not a judicial one.

498 F.2d at 1084 . The court later showed greater willingness to rely on uncertain factual data in its March 14, 1975 decision, which modified the district court injunction to allow Reserve Mining Co. a "reasonable time" to carry out plans for land disposal of the wastes. 514 F.2d at $535-40$.

64. See, e.g., Permian Basin Area Rate Cases, 390 U.S. 747, $801-03$ (1968), where area ratemaking was based on data about costs, supply, and demand from past years. Since the data on earlier years was available, the FPC was obliged to consider it in any predictions as to future costs, supply and demand.

65. Where there is little past experience or statistical data, predictions may seem unusually speculative. See, e.g., International Harvester Co. v. Ruckelshaus, 478 F.2d 615 (D.C. Cir. 1973) (factual basis for establishing the future availability of emission control technology); Friends of the Earth v. EPA, 499 F.2d 118 (2d Cir. 1974) (establishing requirements that will bring local area's air quality within national standards). A court faced with reviewing such uncertain factual determinations under the sliding scale test should evaluate whether the evidence available tends to support the factual conclusions ultimately drawn by the agency. 
tified as great enough that other social losses will be tolerated to avoid it, the statute may also allow action based on incomplete information when it is aimed at avoiding the risk.

Statutes directing administrative agencies to regulate generally "in the public interest" do not typically effect a risk analysis in this sense, nor do they implicitly direct the agency to assess risk. For example, the Federal Communication Commission's policy choices for cable television and the Federal Power Commission's regulation of natural gas pricing ${ }^{\text {si }}$ do not ordinarily involve such policy ranking. However, such a congressional mandate has been established explicitly or implicitly in a number of recent regulatory statutes designed to protect public health and safety in the automobile, ${ }^{67}$ in the home, ${ }^{68}$ at work, ${ }^{60}$ and in the general environment. ${ }^{70}$ In such statutes, Congress has directed the agency to protect the public health even though considerable economic dislocation may result. ${ }^{71}$

The two factors of factual certainty and social risk assessment derived from the cases thus should be combined to produce a sliding scale standard for factual review of informal rulemaking decisions. The structure of judicial review incorporating the sliding scale standard would involve three distinct conclusions: whether the relevant facts are "determinable" and whether Congress or the agency has made any risk assessment; whether the facts adduced meet the adjusted level of proof; and whether the policy choice can rationally rest on that factual base. The degree of factual support necessary should be recognized as varying directly with the determinability of the relevant data, and inversely with the societal risk addressed by the regulation. Whether denominated substantial evidence or arbitrary and capricious review,

66. However, in Mobil Oil Corp. v. FPC, 417 U.S. 283, 331 (1974), the Court apparently assumed that the widespread national concern about the energy crisis could be viewed as readjusting the FPC's generalized responsibility of regulating in the public interest. Because the Court's recognition of "society-wide" risk assessment conflicted neither with a specific risk assessment made by Congress in enacting the Natural Gas Act, 15 U.S.C. $\$ \$ 717$ (c), $71 \%$ (d) $(1970)$, nor with the implementing agency's assessment, the Court's acceptance of a lower standard of factual proof may have been appropriate. Such a holding would be suspect as a judicial amendment of a legislative enactment, however, if a court recognized a social risk which conflicted with an earlier specific congressional risk assessment, even if seemingly outdated.

67. National Traffic and Motor Vehicle Safety Act of 1966, 15 U.S.C. $\$ \$ 1381-1431$ (1970); Clean Air Act, 42 U.S.C. \$ 1857 (1970).

68. Federal Insecticide, Fungicide and Rodenticide Act, 7 U.S.C. $\$ \S 135-135$ (k) (1970); Flammable Fabrics Act, 15 U.S.C. $\$ \$ 1191-1204$ (1970); Delaney Amendments of 1958, Food, Drug and Cosmetic Act, 21 U.S.C. $\$ 348(c)(3)(A)(1970)$.

69. Occupational Safety and Health Act, 29 U.S.C. $\$ \$ 651-78$ (1970).

70. Clean Air Act, 42 U.S.C. $\$ 1857$ (1970).

71. In enacting the National Traffic and Motor Vehicle Safety Act, the Congress concluded that "safety shall be the overriding consideration in the issuance of standards." S. REP. No. 1301, 89th Cong., 2 d Sess. 6 (1966). See also the debate on the Clean Air Act in regard to automobile emissions, note 76 infra. 
this flexible standard can assure reasoned decisionmaking across a wide variety of dissimilar agency policy determinations. ${ }^{72}$

\section{Application of the Sliding Scale Test}

The need for a sliding scale test sensitive to congressional policy ranking is illustrated in two decisions that did not use such a standard of review. In International Harvester $v$. Ruckelshaus, ${ }^{73}$ the court reviewed the Environmental Protection Agency's denial of suspension of car emission standards for one year under the Clean Air Act. ${ }^{74}$ The statutory conditions for suspension did not authorize EPA to give weight to the economic costs of implementing the standards; suspension could be granted under the act only if control technology was unavailable. The Harvester court, however, undertook an expansive estimate of the economic burdens likely to result if the regulations were put into effect while the technology was still imperfect. In sliding scale terminology, the court held that its own estimate of an adverse economic effect from emission standards justified requiring a high level of factual support for a finding of technological availability. ${ }^{75}$ In so doing, the court ignored Congress's decision to alleviate the risk to health ${ }^{76}$ (which should permit a lower standard of proof based on predictions) and Congress's unwillingness to give the implementing agency or the courts any power to reach a different policy accommodation between considerations of cost and public health. ${ }^{77}$

72. Any extension of the sliding scale approach to adjudication and formal rulemaking would turn on whether Congress's specification of relatively formal procedures is to be read as also requiring an unvarying high degree of factual certainty to justify agency action.

If formality of procedure does correlate with formality of proof, the sliding scale standard would be applicable to nonformalized decisionmaking. The wide policy discretion typically conferred upon agencies under regulatory acts using nonformalized decision. making might allow action based on "uncertain" factual data to be upheld in any event. See note 22 supra.

73. 478 F.2d 615 (D.C. Cir. 1973).

74. 42 U.S.C. $\$ 1857$ f-l(b) (1970).

75. 478 F.2d at 636.41 .

76. The sponsors of the Clean Air Act repeatedly stated that Congress was making a policy decision on public health grounds regardless of economic consequences. Sce, e.g., 116 Cong. REc. $32901-04$ (1970) (remarks of Sen. Muskie):

The first responsibility of Congress is not the making of technological or economic judgments-or even to be limited by what is or appears to be technologically or economically feasible. Our responsibility is to establish what the public interest requires to protect the health of persons.

Id. at 32901-02.

77. In effect the Harvester court construed the statute as establishing the real deadline for emission control as 1976, not 1975. That construction is not required by the statute or its legislative history; indeed, both suggest the opposite result. For example, even the broadest suspension condition, allowing the EPA administrator to consider the public interest, provides that the suspension be "essential to the public interest." It is difficult to read such a directive as permitting any easy reevaluation of the original congressional policy decision in favor of a 1975 deadline. 42 U.S.C. $\$ 1857 \mathrm{f}-1$ (b) (1970). 
Ethyl Corp. v. EPA ${ }^{7 s}$ reviewed regulations under the Clean Air Act for the phased reduction of the lead content of motor vehicle gasoline. In the first opinion in the case (subsequently vacated upon rehearing en banc), a panel of the D.C. Circuit interpreted the EPA administrator's statutory authority to control the manufacture and sale of motor vehicle fuel or additives "if any emissions products of such fuel or fuel additives will endanger the public health or welfare." ${ }^{2} 9$ The factual basis for regulating lead in fuel was some showing that lead emitted from cars could be inhaled or ingested with effect on blood lead levels. Examining the legislative history, comparing the "will endanger" standard to other regulatory standards in the act, and treating the phrase "as a matter of plain English meaning,"so the court concluded that the "will endanger" standard required a present ability to demonstrate actual present harm to health from exposure to lead emissions from auto fuel rather than a prediction of harm. ${ }^{81}$ The court rejected the inferences drawn by the agency as to risk on the ground that no single study could conclusively demonstrate that lead emissions caused a sufficient health hazard to a significant portion of the population. ${ }^{82}$

The statutory directive to consider all relevant medical and scientific evidence available in fact set no minimum on the level of scien-

78. 7 ENVIRoN. REP. CAS. 1353 (D.C. Cir. Jan. 28, 1975), vacated on order granting rehearing en banc, No. 73-2205 (D.C. Cir. Mar. 17 , 1975), reheard en banc (D.C. Cir. May $30,1975)$.

79. 42 U.S.C. $\$ 1857 \mathrm{f}-6 \mathrm{c}(\mathrm{c})(1)(1970)$ (emphasis added).

80. Ethyl Corp. v. EPA, 7 Environ. Rep. CAs. 1353, 1361 (D.C. Cir. Jan. 28, 1975).

81. Id. at 1357. The Ethyl court's discussion is often contradictory; it approves the agency's assertion that meeting the "will endanger" standard depends on the cumulative effect of exposure to auto emissions and all other sources of lead. Yet the court then insists that the health hazard must be traced to auto emissions alone, requiring a "measureable increment of lead [that] . . . causes a significant health hazard." Id. (emphasis omitted).

82. The EPA offered as evidence a controlled diet and air exposure study indicating that inhaled lead did result in higher blood lead levels, and other studies showing statistical correlations between emission exposure and blood levels. The Ethyl majority nonetheless rejected the factual conclusions drawn by the agency, because the studies were based on correlations, were limited to a few subjects, or did not isolate the impact of auto emissions from the effect of dietary ingestion of lead. The majority failed to recognize the cumulative character of scientific evidence. Id. at 1369-73. See id. at 140313 (dissenting opinion by Wright, J., giving an cxtensive review of weaknesses in the scientific analysis underlying the majority opinion).

Ethyl was reviewed under the arbitrary and capricious standard. Id. at 1367. Yet even by the traditional interpretation of the substantial evidence standard, the majority in Ethyl clearly exceeded the proper scope of review. The Elhyl majority repeatedly drew inferences in conflict with EP.A, and then rejected EPA's inferences without evaluating whether they were rational as well.

The majority relied on Overton Park's statement that review under the "arbitrary and capricious" standard requires determination of whether there has been a "clear crror of judgment." Ethyl Corp. v. EPA, 7 ENviron. Rer. CAs. 1353, 1367 (D.C. Cir. Jan. 28, 1975), citing Citizens to Preserve Overton Park v. Volpe, 401 U.S. 402, 416 (1971); see p. 1754 supra. Judge Wright's dissent correctly points out that Overton's "clear crror of judgment" language is confusingly similar to the "clearly erroneous" standard used by an appellate court in review of a lower court. The similarity in language may tempt an appellate court to review agency determinations as rigorously as it would those of lower courts. Ethyl Corp. v. EPA, supra at 1400.01 n.57, 1402 n.63. 
tific certainty required before the agency could act. Under the sliding scale standard, the impossibility of certainty in identifying the effect of a pollutant on health would by itself rationalize reducing the level of proof required of the EPA; the level of required certainty should have been even lower given the congressional decision to protect public health.

\section{Conclusion}

Congressional and agency policymaking, and judicial review of that process, have converged most uneasily in the area of complex technical decisionmaking.

In factual review of informal rulemaking under the Administrative Procedure Act, Supreme Court decisions in Overton Park, AlleghenyLudlum, and Midwest Video suggest that the substantial evidence standard applies. A clear holding that substantial evidence is the required standard would held to ensure that judicial scrutiny of informal rulemaking is sufficiently searching.

A reviewing standard that explicitly recognizes flexibility in factual review has also become essential. This Note proposes a "sliding scale" test, varying the required degree of factual support according to the availability of relevant data and the societal risks the regulation alleviates, as gauged by the Congress or the implementing agency. A flexible standard of factual review would avoid the excessively harsh review seen in Harvester and Ethyl, which can frustrate congressional provision for control of technology and protection of health. 